\title{
Air Quality Changes in a Museum Damaged by a Tsunami - Whale and Sea Museum, Iwate, Japan -
}

\author{
MATSUI Toshiya ${ }^{1}$ | KAWASAKI Emi* | Imme Hüttmann** \\ Faculty of Arts and Design, University of Tsukuba, Tsukuba, 305-8574, Japan \\ *Planning Department, Archaeological Institute of Kashihara, Nara prefecture, Kashihara, 634-0065, Japan \\ **Research and Evaluation Department, Oregon Museum of Science and Industry, Oregon, 97214, USA \\ ${ }^{1}$ Corresponding Author: t-matsui@heritage.tsukuba.ac.jp, +81-9028844683
}

\begin{abstract}
This paper provides quantitative data that describes the evolution of the air quality in the Whale and Sea Museum, located in the Iwate prefecture, collected after the 2011 Great East Japan Earthquake and tsunami. The museum was damaged significantly by the disaster, and restoration works continued for over six years. The air quality in the temporary storage facility and museum was monitored during the rehabilitation process. Evaluation of air quality is carried out by gas chromatography- mass spectrometry, ion chromatography and high-performance liquid chromatography. The results showed that the characteristics of the chemical components differed depending on the measurement locations inside the building. The museum atmosphere tended to be alkaline as the airtightness increased because of the maintenance works at the entrance. It was also determined that it was necessary to study the intake/exhaust routes and to clean them according to the contamination degree. In Japan, there are recommended museum air quality standards for acetic acid, formic acid, alkali, and aldehydes. The results indicated that these standards should not be used as a reference for damaged museums. Furthermore, at the temporary storage facilities for to store the collections during the rehabilitation of the museum, solvents such as ethyl benzene, toluene, and xylene are initially abundant, although they can be reduced by ventilation, while other components such as $2 \mathrm{E} 1 \mathrm{H}$ was confirmed in this case are likely to remain.
\end{abstract}

Key Words: Air quality, Disaster, VOC, Museum

\section{INTRODUCTION}

Wide-area disasters can potentially cause critical damage to museums, greatly affecting their facilities and collections. The Great East Japan Earthquake of March 2011 was followed by a powerful tsunami that flooded several museums, effectively halting their operations. Such natural disasters heavily impact communities, and building up regional identity while preserving memories of the phenomenon in affected areas is key when establishing local resilience. The role of such efforts has recently gained attention (Aldrich and Meyer, 2015; Izumi, 2015), as has recognition of local cultures and their value for rebuilding affected areas (Mugikura and Yoshino, 2013). Taking these findings into consideration, museums can have an important role in their community, and after the 2011 earthquake, their reconstruction was addressed by the Japanese government.

A historical materials conservation network was established(Okada, 2017), which until now addressed the disasters by region(for example, at the prefectural level), making post-disaster efforts to preserve affected regional historical materials regardless of designation as cultural properties.

Research on stabilization treatments for various damaged materials has been developed, while the number of case studies increased(Spafford-Ricci and Graham, 2000a; 2000b; FAIC, 2006; ICOM Japan, 2015; 2018).

While there are many cases where architectural diagnoses determine whether a damaged museum is stable enough for reuse, there are no examples previous to 2011 of research on the quantitative values and subsequent trends of the postdisaster environment inside the museum, especially on air quality. 
The importance of monitoring air quality has so far been overlooked. Damage to museums caused by conventional natural disasters had been relatively small, and damaged areas had not been significantly wide, so that related organizations conventionally focused on implementing quick rescue and restoration operations. However, addressing the museums affected by the 2011 Great East Japan Earthquake would take several years, a time during which the collections, regardless of their damage status, had to be stored in damaged museum facilities.

Regarding the air quality of damaged facilities, Matsui et al. have reported on the changes that occurred throughout time for a museum located in the city of Ishinomaki, in the Miyagi prefecture(Matsui et al., 2012; 2013; 2014; 2015)

It is easy to imagine that the air components in disasterstruck storage facilities are not found in conventional museum spaces. However, in the case of wide-area natural disasters, collections must be placed for a long time in affected facilities, as there are no alternative ways to secure storage locations. Environmental storage conditions worsen increasingly, as air conditioning is oftentimes not running due to power shortages, which limits the possibility of offering adequate storage and management for the materials. These conditions do not only affect damaged collections; materials that did not suffer direct impact can also be affected, as they can adsorb various components by being in a disaster-struck space for a long time. In the case of materials that were placed in temporary storage after their rescue, there is concern that they might contaminate the air by re-emitting previously adsorbed substances, a form of secondary contamination risk which is important to consider.

A number of authors conducted research on the gas components released by the affected materials after the Great East Japan Earthquake. In an analysis on the volatile substances of disaster-damaged paper, Oikawa et al.(2018) found differences attributed to the type of disaster -either flood or tsunami- and the applied drying method, and explored the influence of volatile substances that cause offensive odor on cultural properties with an increase in concentration(Oikawa and Haga, 2017). Matsushita et al.(2018) discovered methyl disulfide and chloroform in the water used for treating rescued historic documents. Sano et al. (2017) considered that organic matter and microorganisms in the sludge could be causes for the offensive odor in tsunami-affected paper materials before and after desalination treatment, and proposed measures to reduce these odors. Uchida et al.(2018) support this view, pointing at the increase of bacteria during the process of stabilization treatment of tsunami-affected paper materials as one cause of odor. Kotajima et al.(2018) are investigating naphthalene in the insecticide used to preserve the materials in the storage environment. So far, several studies have addressed gaseous components emitted from disaster-struck materials and the types of gases found in affected buildings. However, there is no research showing the values of the air components and what their trends are as reconstruction advances.

The aim of this paper is to address the aforementioned gaps by monitoring the air quality during the process of rebuilding a damaged museum as well as in its temporary storage facility. In doing so, we intended to evaluate the influence of the damaged museum air against materials that underwent treatment and their effect in their corresponding storage space. Additionally, we aimed at pointing out any problems that arose from stabilization treatments and storage by measuring the air quality during the process of stabilization and in the temporary storage facility several years after the disaster.

\section{THE WHALE AND SEA MUSEUM}

\subsection{Building overview}

In 1988, shortly before commercial whaling was banned, a large sperm whale with a body length of 17.6 meters and a body weight of 60 tons was captured. The whale's skeletal specimen was extracted at that time for future generations to admire. To exhibit this specimen, the Whale and Sea Museum was inaugurated in 1992 in Yamada, Iwate prefecture, Japan(Figure 1). The building of the museum has a reinforced concrete structure with a partial steel frame. It lies two stories above ground and measures $9.4 \mathrm{~m}$ 
high, with a building area of $1,336 \mathrm{~m}^{2}$ and a floor area of $1,973 \mathrm{~m}^{2}$. On the floor area is a dome that has a radius of $13.0 \mathrm{~m}$ and a maximum height $23.8 \mathrm{~m}$. A plan view is shown in Figure 2.

\subsection{Post-disaster conditions}

The tsunami that followed the Great East Japan Earthquake caused damage to numerous parts of the facilities. The outer wall was partially missing due to collisions with drifting debris. Although there was a partial collapse of the entrance

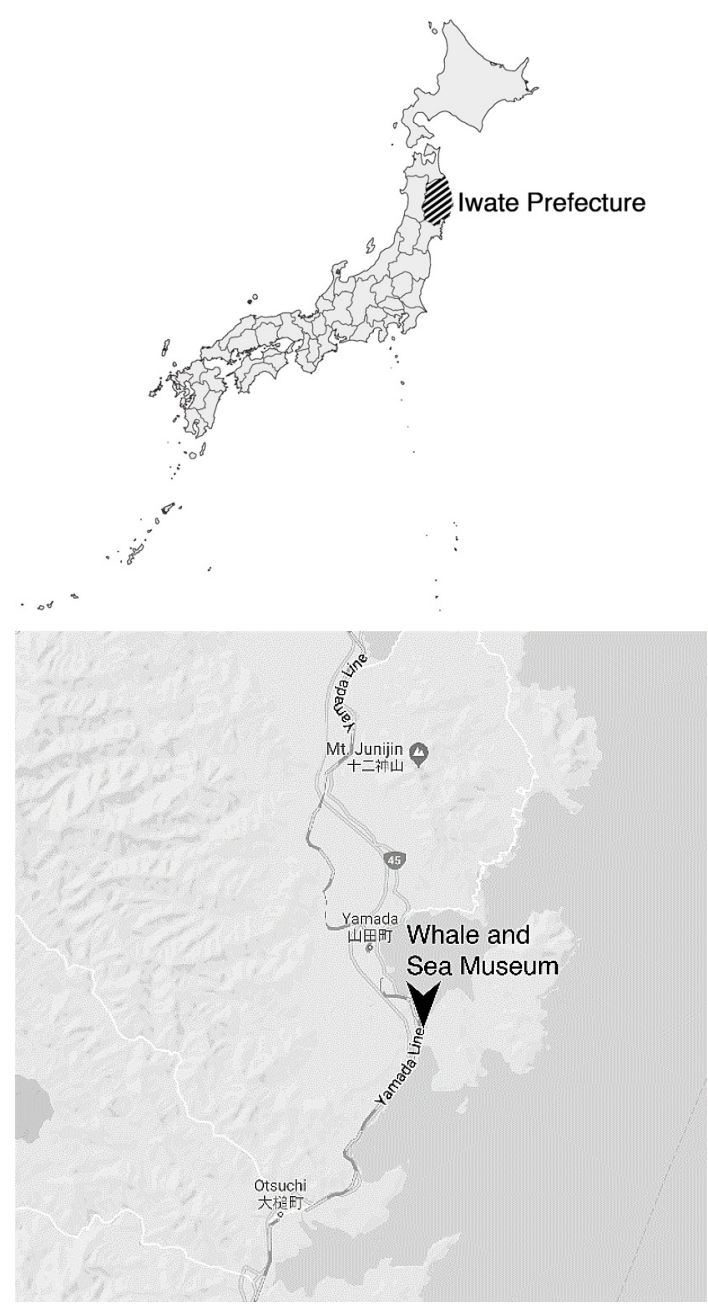

Figure 1. Location of Iwate prefecture(striped, upper image) and the bay in Yamada(lower image). The black arrow shows the location of the museum. slope, there was no serious structural damage, but in the hall facilities such as air conditioning equipment, boilers, and oil storage furnishings were damaged. Equipment that belonged to the office and research facilities, such as desks, chairs, personal computers, copy machines, printers, and microscopes were lost or unusable. Electric facilities such as indoor, outdoor, and night lighting were also damaged due to the flood. The tsunami flooding level reached about $8 \mathrm{~m}$ from the ground. The state of the museum at the time of the disaster is shown in Figure 3.

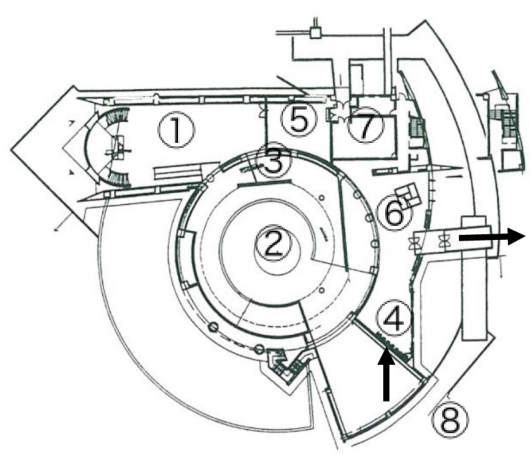

Figure 2. Platform of museum(1) The display room for the hanging sperm whale skeleton (2) Promenade display room (3) Underground pit (4) Entrance lounge(2F) (5) Storehouse (6) Museum shop (7) Machine room (8) Outdoors). The black arrow shows the location of the doorway.

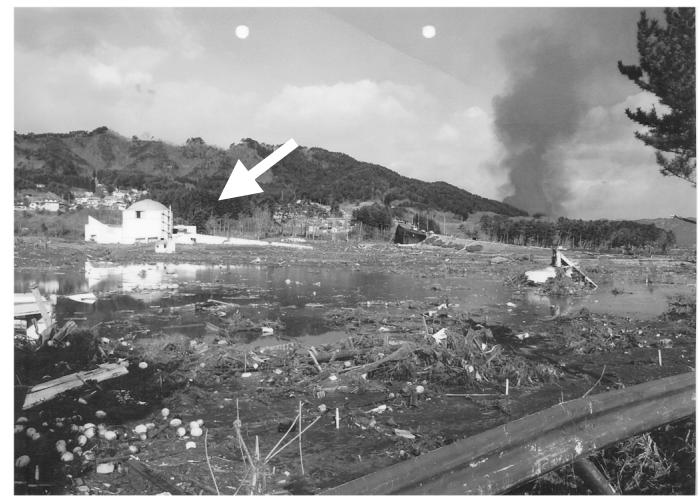

Figure 3. The museum after the tsunami shown by the arrow. 
Table 1. Timeline of the Whale and Sea Museum restoration

\begin{tabular}{ccl}
\hline \multicolumn{2}{c}{ Date } & \multicolumn{1}{c}{ Event } \\
\hline 2011 & March & Disaster \\
\hline & April & $\begin{array}{l}\text { Removal of debris, start of rescuing of collection materials(water washing), } \\
\text { washed materials were stored in the tent and hall }\end{array}$ \\
\hline & May-August & Examination of the status of the hanging skeleton, water washing \\
\hline 2012 & December & Current status diagnosis by the Cultural Property Relief Committee, cleaning \\
\hline 2013 & August & Beginning of the anoxic treatment(for 2 years) \\
\hline 2014 & April-July & The materials were transferred to the temporary storage facilities \\
\hline & August & Beginning of material stabilization treatment at the temporary storage facilities \\
\hline 2015 & July-September & Cleaning and refurbishing of the main hall \\
\hline & March-June & Construction of the display equipment \\
\hline October & Transferring stabilized material to the collection room of the main hall \\
\hline 2016 & November & Fumigation of the skeleton hall \\
\hline 2017 & August & Fumigation of the main room \\
\hline
\end{tabular}

\subsection{The reconstruction process of the museum}

Removal of debris and rescue of the collections were carried out the following month. After that, a preliminary cleaning of the large skeletal specimen in the hall was carried out. In order to inhibit the deterioration of the collection, an oxygen absorbency treatment was applied using high gas barrier film in August 2012. The skeletal specimen room was fumigated, and cleaning and maintenance works of the interior began. Meanwhile, the collection was transferred to temporary storage facilities, and treatments continued to support the future exhibition and use of the collection once the museum was reconstructed. The museum was reopened in July 2017. The time series of these main tasks are shown in Table 1.

While the restoration works at the museum continued, temporary storage facilities were built in which the affected materials were stabilized(Kawasaki et al., 2017). Figure 4. shows the three storage rooms, each with a capacity of about $83 \mathrm{~m}^{3}$. The facilities are prefabricated flat buildings with a total length of $36 \mathrm{~m}$, and a total area of $324 \mathrm{~m}^{2}$, built on the concrete foundation that was established after flattening the land adjacent to the building. In these temporary facilities people were constantly entering and leaving, as the buildings served as office rooms and spaces to carry out stabilization processes.
Gypsum boards and zeolite humidity conditioning boards were used on the wall and ceiling, and ceiling ventilators and dehumidifiers were installed. The objects transferred from the library were cleaned and stabilized in the treatment room and stored in the storage room depending on the material they were made of. Temperature and humidity data loggers and insect traps were placed in each storage room and were monitored.

Two air quality surveys were conducted in September 2014 and September 2015. The facilities have been demolished because the museum hall was reopened.

\section{ANALYSIS METHODS}

The analyzed substances were organic acids, inorganic acids, alkali, aldehyde, VOC gases, airborne bacteria, and acidity. The conditions for each measurement are shown in Table 2 .

The measurements were conducted at the museum three times: two years and nine months after the disaster (December 2013), four years and six months(September 2015), and seven years and five months(August 2018) after the disaster. In the temporary storage facilities, it was carried out after their construction in September 2014 and one year later. The instrument details for analysis are detailed in Table 3. 

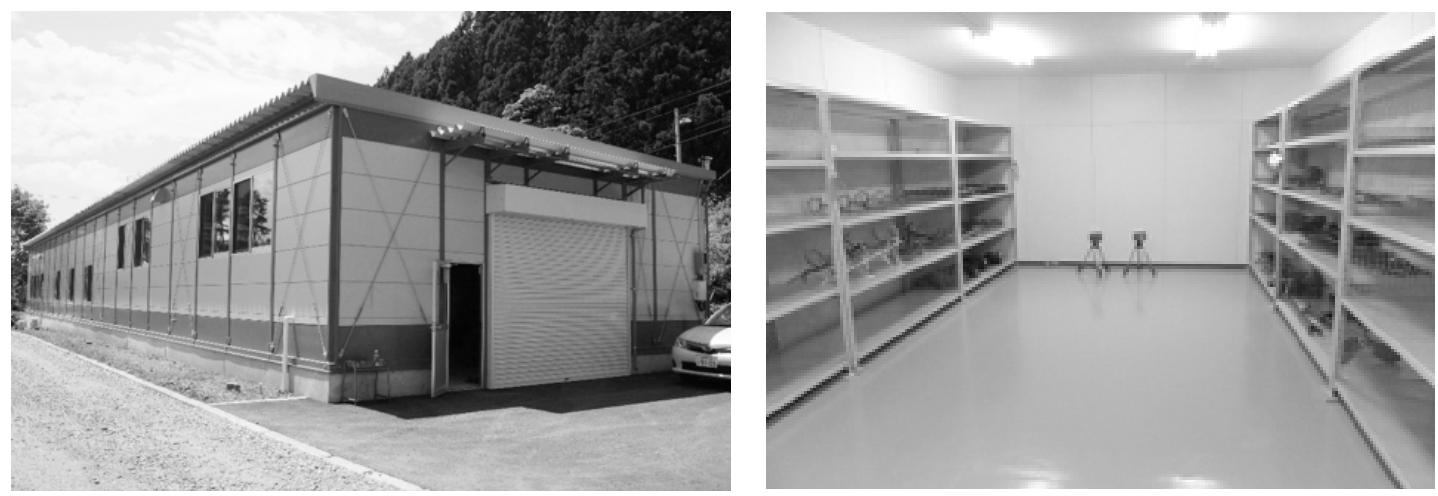

Figure 4. The temporary storage facilities.

Table 2. Measurement details

\begin{tabular}{cccc}
\hline Target substance & Method & Flow rate (L/min) & Time (h) \\
\hline Organic acids & Impinger capture / IC analysis & 1.0 & 24 \\
\hline Inorganic acids, alkali & Impinger capture / IC analysis & 1.0 & 24 \\
\hline Aldehydes & DNPH capture / HPLC analysis & 0.5 & 2 \\
\hline Organic gases & TENAX capture / GC-MS analysis & 1.0 & 1.5 \\
\hline Airborne bacteria & Air sampler & 100 & 2 min \\
\hline
\end{tabular}

Table 3. Measurement instruments

\begin{tabular}{|c|c|c|}
\hline Analytical instrument & & Specification \\
\hline \multirow{6}{*}{ GC-MS } & Model & $\begin{array}{c}\text { GC }: 7890 B \text { MS : 5977A } \\
\text { (Agilent Technologies, USA) }\end{array}$ \\
\hline & Column & $\begin{array}{c}\text { Inert Cap } 1 \\
(60 \mathrm{~m} \| 0.25 \mathrm{~mm} \text { I.D. } \uparrow 0.4 \mu \mathrm{m})\end{array}$ \\
\hline & Oven temp. & $40^{\circ} \mathrm{C}(5 \mathrm{~min})-10^{\circ} \mathrm{C} / \min -280^{\circ} \mathrm{C}(11 \mathrm{~min})$ \\
\hline & Carrier gas & $\mathrm{He}$ \\
\hline & Injector temp. & $300^{\circ} \mathrm{C}$ \\
\hline & Ionization model & EI $70 \mathrm{eV}$ \\
\hline \multirow{4}{*}{ Ion Chromatography } & Model & $\begin{array}{c}\text { ICS-5000 } \\
\text { (Thermo Fisher Scientific, USA) }\end{array}$ \\
\hline & Column & $\begin{array}{c}\text { Ion Pac AG17-C/AS17-C } \\
\text { and CG17/CS17 }\end{array}$ \\
\hline & Eluent & $\begin{array}{l}\text { Potassium hydroxide } \\
\text { (1-40 mol/L Gradient) }\end{array}$ \\
\hline & Suppressor & AERS 500 and CERS 500 \\
\hline \multirow{4}{*}{ HPLC } & Model & LC-10ADvp(Shimazu, JPN) \\
\hline & Column & Shim-pack FC-ODS \\
\hline & Solvent & Water/Acetonitrile $=50 / 50(\mathrm{v} / \mathrm{v} \%)$ \\
\hline & Detection & UV360 nm \\
\hline
\end{tabular}


Table 4. Measurement results. The numerical value indicates the measurement period: Aug.2018 [Sep.2015] (Dec.2013)

\begin{tabular}{|c|c|c|c|c|c|c|c|c|c|c|c|}
\hline & & $\begin{array}{c}\text { Skeleton } \\
\text { display } \\
\text { room }\end{array}$ & $\begin{array}{c}\text { Promenade } \\
\text { display } \\
\text { room }\end{array}$ & $\begin{array}{l}\text { Undergro } \\
\text { und pit }\end{array}$ & Lounge & $\begin{array}{l}\text { Storage } \\
\text { room }\end{array}$ & Shop & $\begin{array}{l}\text { Machine } \\
\text { room }\end{array}$ & $\begin{array}{l}\text { Special } \\
\text { exhibition } \\
\text { room }\end{array}$ & Outside & $\begin{array}{l}\text { Recom- } \\
\text { mended } \\
\text { values* }\end{array}$ \\
\hline \multirow[t]{2}{*}{$\begin{array}{l}\text { Organic } \\
\text { acid }\end{array}$} & $\begin{array}{l}\text { Acetic } \\
\text { acid }\end{array}$ & $\begin{array}{c}14.1 \\
{[10.2]} \\
(3.0)\end{array}$ & $\begin{array}{l}14.6 \\
{[7.3]} \\
<0.3\end{array}$ & $\begin{array}{c}- \\
{[0.09]} \\
(<0.3)\end{array}$ & $\begin{array}{c}19.1 \\
{[12.9]} \\
(-)\end{array}$ & $\begin{array}{c}12.2 \\
{[6.78]} \\
(-)\end{array}$ & $\begin{array}{c}10.7 \\
{[8.18]} \\
(-)\end{array}$ & $\begin{array}{c}- \\
{[0.26]} \\
(-)\end{array}$ & $\begin{array}{l}9.3 \\
{[-]} \\
(-)\end{array}$ & $\begin{array}{c}<0.1 \\
{[0.05]} \\
(1)\end{array}$ & $<430$ \\
\hline & $\begin{array}{l}\text { Formic } \\
\text { acid }\end{array}$ & $\begin{array}{l}1.8 \\
{[1.8]} \\
(0.3)\end{array}$ & $\begin{array}{c}2.2 \\
{[1.6]} \\
(<0.1) \\
\end{array}$ & $\begin{array}{c}- \\
{[0.08]} \\
(0.1)\end{array}$ & $\begin{array}{c}3.1 \\
{[3.52]} \\
(-) \\
\end{array}$ & $\begin{array}{c}2.9 \\
{[1.49]} \\
(-)\end{array}$ & $\begin{array}{c}1.3 \\
{[1.42]} \\
(-)\end{array}$ & $\begin{array}{c}- \\
{[0.24]} \\
(-)\end{array}$ & $\begin{array}{c}1 \\
{[-]} \\
(-)\end{array}$ & $\begin{array}{c}<0.3 \\
{[0.14]} \\
(0.2)\end{array}$ & $<20$ \\
\hline \multirow[t]{4}{*}{$\begin{array}{l}\text { Inorganic } \\
\text { acid }\end{array}$} & $\mathrm{Cl}^{-}$ & $\begin{array}{c}0.3 \\
{[0.1]} \\
(<0.1) \\
\end{array}$ & $\begin{array}{c}0.1 \\
{[0.2]} \\
(<0.1) \\
\end{array}$ & $\begin{array}{c}- \\
{[0.01]} \\
(<0.1)\end{array}$ & $\begin{array}{c}0.5 \\
{[0.1]} \\
(-) \\
\end{array}$ & $\begin{array}{c}<0.1 \\
{[0.35]} \\
(-)\end{array}$ & $\begin{array}{c}0.9 \\
{[0.15]} \\
(-)\end{array}$ & $\begin{array}{c}- \\
{[0.03]} \\
(-)\end{array}$ & $\begin{array}{l}0.2 \\
{[-]} \\
(-)\end{array}$ & $\begin{array}{c}1 \\
{[2.08]} \\
(0.4)\end{array}$ & \\
\hline & $\mathrm{NO}_{2}^{-}$ & $\begin{array}{c}1 \\
{[1.8]} \\
(0.7)\end{array}$ & $\begin{array}{c}1 \\
{[1.7]} \\
(2.4)\end{array}$ & $\begin{array}{c}- \\
{[0.07]} \\
(0.3)\end{array}$ & $\begin{array}{c}1 \\
{[2.98]} \\
(-)\end{array}$ & $\begin{array}{c}0.7 \\
{[1.22]} \\
(-)\end{array}$ & $\begin{array}{c}0.6 \\
{[1.37]} \\
(-)\end{array}$ & $\begin{array}{c}- \\
{[0.87]} \\
(-)\end{array}$ & $\begin{array}{c}1 \\
{[-]} \\
(-) \\
\end{array}$ & $\begin{array}{c}<0.1 \\
{[0.03]} \\
(0.2) \\
\end{array}$ & \\
\hline & $\mathrm{NO}_{3}{ }^{-}$ & $\begin{array}{c}0.2 \\
{[0.03]} \\
(0.1) \\
\end{array}$ & $\begin{array}{c}<0.1 \\
{[<0.1]} \\
(<0.1) \\
\end{array}$ & $\begin{array}{c}- \\
{[<0.01]} \\
(<0.1)\end{array}$ & $\begin{array}{c}0.2 \\
{[0.23]} \\
(-) \\
\end{array}$ & $\begin{array}{c}<0.1 \\
{[0.51]} \\
(-)\end{array}$ & $\begin{array}{c}<0.1 \\
{[0.18]} \\
(-)\end{array}$ & $\begin{array}{c}- \\
{[0.03]} \\
(-)\end{array}$ & $\begin{array}{c}<0.1 \\
{[-]} \\
(-) \\
\end{array}$ & $\begin{array}{c}<0.1 \\
{[1.75]} \\
(0.5) \\
\end{array}$ & \\
\hline & $\mathrm{SO}_{4}{ }^{2-}$ & $\begin{array}{c}0.3 \\
{[0.2]} \\
(0.2) \\
\end{array}$ & $\begin{array}{c}0.1 \\
{[0.1]} \\
(0.2) \\
\end{array}$ & $\begin{array}{c}- \\
{[0.04]} \\
(0.1)\end{array}$ & $\begin{array}{c}0.1 \\
{[0.15]} \\
(-) \\
\end{array}$ & $\begin{array}{c}<0.1 \\
{[0.21]} \\
(-)\end{array}$ & $\begin{array}{c}0.2 \\
{[0.21]} \\
(-)\end{array}$ & $\begin{array}{c}- \\
{[0.07]} \\
(-)\end{array}$ & $\begin{array}{l}0.1 \\
{[-]} \\
(-)\end{array}$ & $\begin{array}{c}0.3 \\
{[1.66]} \\
(0.9)\end{array}$ & \\
\hline Alkali & $\mathrm{NH}_{4}^{+}$ & $\begin{array}{c}7.1 \\
{[16.4]} \\
(4.8)\end{array}$ & $\begin{array}{c}9.4 \\
{[17.1]} \\
(4.7) \\
\end{array}$ & $\begin{array}{c}- \\
{[34.9]} \\
(2.5)\end{array}$ & $\begin{array}{c}5.6 \\
{[13.9]} \\
(-) \\
\end{array}$ & $\begin{array}{c}4.1 \\
{[7.5]} \\
(-) \\
\end{array}$ & $\begin{array}{c}6.0 \\
{[13.4]} \\
(-)\end{array}$ & $\begin{array}{c}- \\
{[25.7]} \\
(-)\end{array}$ & $\begin{array}{l}- \\
{[-]} \\
(-)\end{array}$ & $\begin{array}{c}0.5 \\
{[0.3]} \\
(0.5) \\
\end{array}$ & \\
\hline VOC & & $\begin{array}{c}34 \\
{[365]} \\
(102) \\
\end{array}$ & $\begin{array}{c}55 \\
{[568]} \\
(88) \\
\end{array}$ & $\begin{array}{c}- \\
{[74]} \\
(51) \\
\end{array}$ & $\begin{array}{c}38 \\
{[208]} \\
(-) \\
\end{array}$ & $\begin{array}{c}69 \\
{[186]} \\
(-) \\
\end{array}$ & $\begin{array}{c}43 \\
{[213]} \\
(-) \\
\end{array}$ & $\begin{array}{c}- \\
{[237]} \\
(-)\end{array}$ & $\begin{array}{l}56 \\
{[-]} \\
(-) \\
\end{array}$ & $\begin{array}{c}2 \\
{[22]} \\
(6) \\
\end{array}$ & \\
\hline \multirow[t]{2}{*}{ Aldehyde } & $\begin{array}{l}\text { Formalde } \\
\text { hyde }\end{array}$ & $\begin{array}{c}13 \\
{[13]} \\
(18) \\
\end{array}$ & $\begin{array}{c}8 \\
{[16]} \\
(11) \\
\end{array}$ & $\begin{array}{c}- \\
{[<2]} \\
(8)\end{array}$ & $\begin{array}{c}8 \\
{[17]} \\
(-) \\
\end{array}$ & $\begin{array}{c}9 \\
{[5]} \\
(-)\end{array}$ & $\begin{array}{c}5 \\
{[17]} \\
(-) \\
\end{array}$ & $\begin{array}{c}- \\
{[12]} \\
(-)\end{array}$ & $\begin{array}{c}6 \\
{[-]} \\
(-)\end{array}$ & $\begin{array}{c}<1 \\
{[<2]} \\
(7)\end{array}$ & $<100$ \\
\hline & $\begin{array}{l}\text { Acetalde } \\
\text { hyde }\end{array}$ & $\begin{array}{c}3 \\
{[11]} \\
(<5) \\
\end{array}$ & $\begin{array}{c}2 \\
{[17]} \\
(<5) \\
\end{array}$ & $\begin{array}{c}- \\
{[<2]} \\
(<5) \\
\end{array}$ & $\begin{array}{c}3 \\
{[15]} \\
(-)\end{array}$ & $\begin{array}{c}2 \\
{[6]} \\
(-) \\
\end{array}$ & $\begin{array}{c}1 \\
{[17]} \\
(-) \\
\end{array}$ & $\begin{array}{c}- \\
{[2]} \\
(-)\end{array}$ & $\begin{array}{c}2 \\
{[-]} \\
(-) \\
\end{array}$ & $\begin{array}{c}<1 \\
{[<2]} \\
(<5) \\
\end{array}$ & $<48$ \\
\hline \multirow{2}{*}{$\begin{array}{l}\text { Airborne } \\
\text { bacteria } \\
(/ 100 \mathrm{~L})\end{array}$} & Fungus & $\begin{array}{c}- \\
{[24]} \\
(22) \\
\end{array}$ & $\begin{array}{c}- \\
{[40]} \\
(17) \\
\end{array}$ & $\begin{array}{c}- \\
{[100]} \\
83\end{array}$ & $\begin{array}{c}- \\
{[31]} \\
(-)\end{array}$ & $\begin{array}{c}- \\
{[14]} \\
(-)\end{array}$ & $\begin{array}{c}- \\
{[188]} \\
(-)\end{array}$ & $\begin{array}{c}- \\
{[140]} \\
(-)\end{array}$ & $\begin{array}{c}- \\
{[-]} \\
(-) \\
\end{array}$ & $\begin{array}{c}- \\
{[8]} \\
(6) \\
\end{array}$ & \\
\hline & Bacteria & $\begin{array}{c}- \\
{[12]} \\
(21) \\
\end{array}$ & $\begin{array}{c}- \\
{[6]} \\
(11) \\
\end{array}$ & $\begin{array}{c}- \\
{[33]} \\
60 \\
\end{array}$ & $\begin{array}{c}- \\
{[9]} \\
(-) \\
\end{array}$ & $\begin{array}{c}- \\
{[10]} \\
(-)\end{array}$ & $\begin{array}{c}- \\
{[100]} \\
(-)\end{array}$ & $\begin{array}{c}- \\
{[56]} \\
(-) \\
\end{array}$ & $\begin{array}{l}- \\
{[-]} \\
(-)\end{array}$ & $\begin{array}{c}- \\
{[12]} \\
(7)\end{array}$ & \\
\hline
\end{tabular}

*Recommended values(Sano et al., 2010)

(Unit: $\mu \mathrm{g} / \mathrm{m}^{3}$ )

The average temperature and relative humidity during the measurements were $4.9^{\circ} \mathrm{C}$ and $66 \mathrm{RH} \%$ in December $2013 ; 21.2^{\circ} \mathrm{C}$ and $88 \mathrm{RH} \%$ in September $2014 ; 19.5^{\circ} \mathrm{C}$ and $96 \mathrm{RH} \%$ in September 2015; and $19^{\circ} \mathrm{C}$ and $98 \mathrm{RH} \%$ in August 2018.

\section{RESULTS AND DISCUSSION}

\subsection{Whale and Sea Museum air quality}

The entrance and windows of the museum were damaged by the disaster, allowing the air from the exterior to continue entering the hall directly for more than a year.

The parking lot of the museum and the surroundings became a rubble storage area, which reached a height of 7 $8 \mathrm{~m}$

After a doorway was installed in 2014 , the inside of the hall became disconnected from the outside, and an increase in alkalinity was observed in all measurement points of the hall. This confirms previous observations in other disasteraffected facilities which became more alkaline following maintenance works of entrances, exits, and others. It is observed as a museum air acidity behavior of the construction 
period that led to the reopening of the hall. Although ventilation rates in airtight spaces are important when calculating air quality, they could not be measured in this case because of the damage and the semi-open conditions of the museum. Measured air quality values show are an average obtained by sampling air for 24 hours, and can only show the values obtained during sampling.

Table 4 shows the results of air quality in the museum. The ammonia concentrations increased more 4 years than 2 years after the disaster. It was thought that as restoration works of the inside of the hall continued, the air exchange rate with the outside air was controlled, while the organic matter, including from the tsunami, had been adsorbed on the concrete walls of the museum and was decomposing. The underground pit constructed for the air handling unit (AHU) of the building connected with the intake duct, and there was concern that the AHU might spread the matter to the entire hall. Due to the influence of the earthquake, this pit remained under water until the reopening of the museum. It was found that it is necessary to study the intake/ exhaust route and to clean it according to its contamination. Additionally, it is necessary to consider a suitable filter to be installed on the AHU.

After reopening, one year after the 2018 survey, the measurements were at or under museum recommended levels $\left(22 \mu \mathrm{g} / \mathrm{m}^{3}\right)$.

Among the additional measured substances, acetic acid, formic acid, formaldehyde, and acetaldehyde were lower than the recommended values of Japanese museums. However, VOC showed high values as the hall interiors were completed, and it became clear that there were numerous organic substances in the air. The VOC results were classified according to their chemical components and compared. Figure 5 shows the comparison of the results of the measurements made in 2013 and 2015 in the whale skeleton display room, the promenade display room, and the underground pit.

It was revealed that alcohols and glycols increased in the underground pit. It was also found that the characteristics of chemical components differed depending on the space in the hall.

\subsection{Air quality in the temporary storage facilities}

The temperature and relative humidity distribution in and outside Storage Room 3 of the temporary storage facilities are shown in Figure 6. The room mainly stored metal objects that underwent stabilization treatment.

As a result of using a dehumidifier, the relative humidity could be suppressed to about $65 \mathrm{RH} \%$ or less, even when the temperature rose during the summer. However, the RH would rise to over $80 \%$ on rainy days, and the materials were examined when it did. Table 5 shows the air quality in

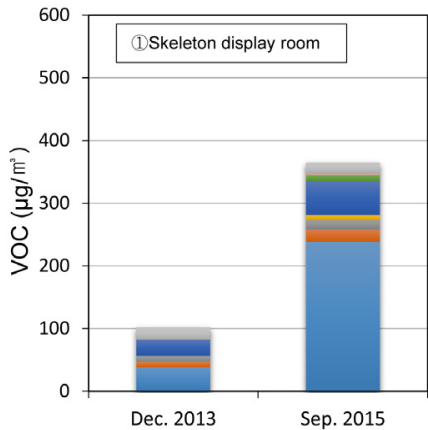

- Siloxanes
Esters

Halides

Aldehydes \& Ketones

- Alcohols \& Glycols

- Organic Acids

Monocyclic $\mathrm{HC}$

Aliphatic $\mathrm{HC}$

Aromatic $\mathrm{HC}$

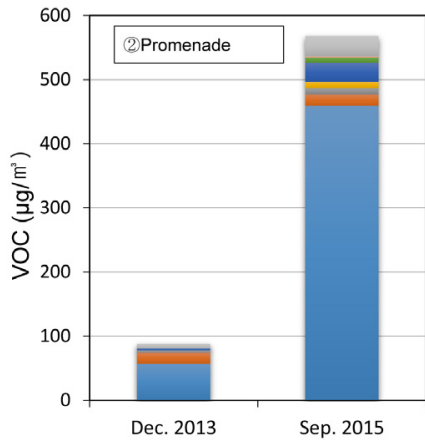

Siloxanes

Esters

Halides

Aldehydes \& Ketones

- Alcohols \& Glycols

arganic Acids

Monocyclic $\mathrm{HC}$

aliphatic $\mathrm{HC}$

aromatic HC

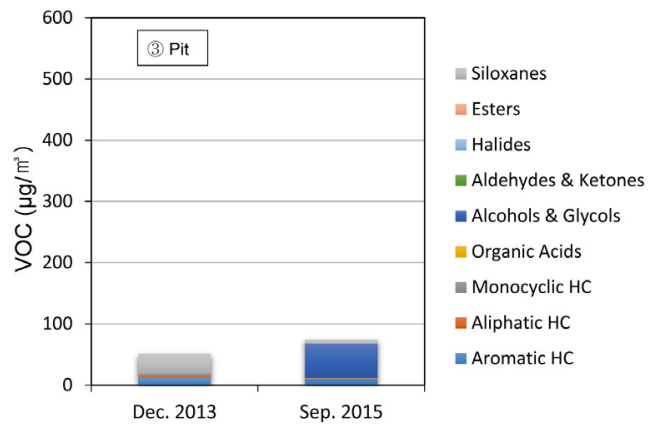

Figure 5. VOC results of 2013 and 2015 according to chemical composition. 
the temporary storage facilities.

Acetic acid, formic acid, ammonia, formaldehyde, and acetaldehyde all fell below the recommended values.

This may be due to the selection of building materials that do not contain these gases at the time of construction of the temporary storage facility. However, VOC emissions were found to be exceptionally high. Figure 7 shows the GC-MS spectrum of Storage Room 3. At the beginning of construction, components originating from paints such as ethylbenzene, toluene, and xylene were found, but by enforcing ventilation, their numbers decreased to almost undetectable levels after one year. However, 2-ethyl-1- hexanol did not show a tendency to decrease. The influence of oxides of 2-ethyl-1-hexanol on cultural objects has been shown by Oikawa and Haga(2016). Flooring materials and adhesives are a possible source of the measured $2 \mathrm{E} 1 \mathrm{H}$, but studies to identify sources were not carried out.

Depending on the chemical components, there are substances likely to remain, and attention should be paid to the air quality of the temporary storage space.

\section{SUMMARY}

In this study, the characteristics of the air quality in a
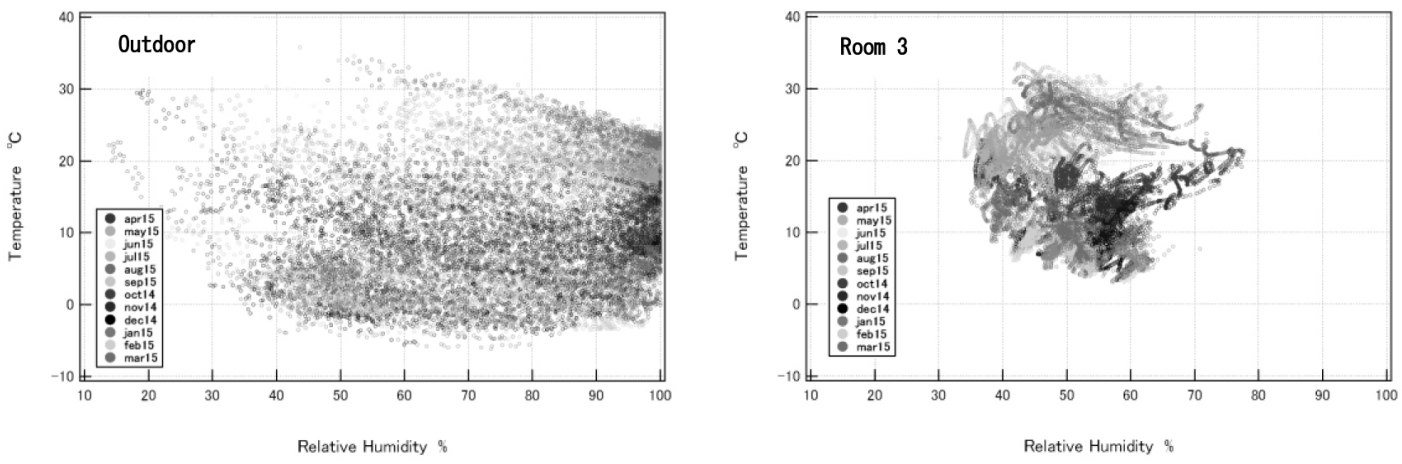

Figure 6. Climograph of temperature and $\mathrm{RH}$ in the temporary storage facilities.

Table 5. Changes in the air quality of the temporary storage facilities

\begin{tabular}{|c|c|c|c|c|c|c|c|c|c|}
\hline \multirow{2}{*}{$\begin{array}{l}\text { Measuring } \\
\text { location }\end{array}$} & \multirow{2}{*}{$\begin{array}{c}\text { Measuring } \\
\text { date }\end{array}$} & \multicolumn{2}{|c|}{ Organic acids } & \multirow{2}{*}{$\frac{\text { Alkali }}{\mathrm{NH}_{4}^{+}}$} & \multirow{2}{*}{$\begin{array}{c}\begin{array}{c}\text { Organic } \\
\text { matter }\end{array} \\
\text { VOC }\end{array}$} & \multicolumn{2}{|c|}{ Aldehydes } & \multicolumn{2}{|c|}{$\begin{array}{c}\text { Airborne } \\
\text { bacteria }(/ 100 \mathrm{~L})\end{array}$} \\
\hline & & $\begin{array}{l}\text { Acetic } \\
\text { acid }\end{array}$ & $\begin{array}{l}\text { Formic } \\
\text { acid }\end{array}$ & & & Formaldehyde & Acetaldehyde & Fungus & Bacteria \\
\hline \multirow{2}{*}{$\begin{array}{l}\text { Storage } \\
\text { room } 1\end{array}$} & Sep, 2014 & 3.4 & 0.6 & 3.7 & 708 & 9 & 12 & 15 & 6 \\
\hline & Sep, 2015 & 4.5 & 1.2 & 4.2 & 205 & 19 & 19 & 25 & 7 \\
\hline \multirow{2}{*}{$\begin{array}{l}\text { Storage } \\
\text { room } 2\end{array}$} & Sep, 2014 & 1.8 & 0.7 & 3.8 & 802 & $<9$ & 15 & 12 & 4 \\
\hline & Sep, 2015 & 9.5 & 1.4 & 3.7 & 358 & 13 & 29 & 50 & 8 \\
\hline \multirow{2}{*}{$\begin{array}{l}\text { Storage } \\
\text { room } 3\end{array}$} & Sep, 2014 & 2.8 & 0.7 & 3.6 & 758 & $<9$ & 25 & 18 & 12 \\
\hline & Sep, 2015 & 8.6 & 1.7 & 4.0 & 369 & 9 & 11 & 16 & 15 \\
\hline \multirow{2}{*}{$\begin{array}{l}\text { Storage } \\
\text { room } 4\end{array}$} & Sep, 2014 & 10.2 & 3.4 & 5.9 & 526 & $<9$ & 16 & 18 & 36 \\
\hline & Sep, 2015 & 4.3 & 1.9 & 4.5 & 147 & 3 & 6 & 43 & 60 \\
\hline \multirow{2}{*}{ Outside } & Sep, 2014 & $<0.1$ & $<0.1$ & 5.9 & 7 & - & - & 26 & 8 \\
\hline & Sep, 2015 & 0.1 & 0.1 & 0.3 & 22 & $<2$ & $<2$ & 8 & 12 \\
\hline $\begin{array}{l}\text { Recom- } \\
\text { mended } \\
\text { values* }\end{array}$ & & $<430$ & $<20$ & $<22$ & - & $<100$ & $<48$ & - & - \\
\hline
\end{tabular}




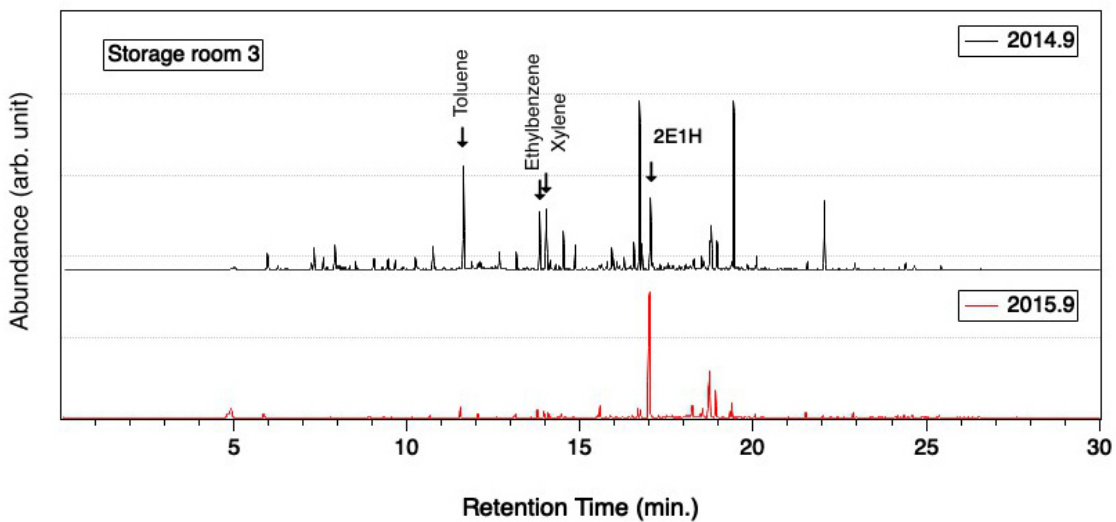

Figure 7. GC-MS results of storage room 3.

museum damaged by the tsunami and its temporary storage facilities were investigated. The following results emerged:

- In the affected facilities, the atmosphere tended to be alkaline with an increase in airtightness due to maintenance works at the entrance.

- It is necessary to study the intake/exhaust routes and to clean them according to the degree of contamination.

- Regarding the reuse of the facilities, general museum environment standards should not be used as a reference, as the effects of flooding and of new exhibition equipment need to be taken into consideration.

- At the temporary storage facilities, solvents such as ethyl benzene, toluene, and xylene initially abound and can be reduced by ventilation. However, the presence of components that are likely to remain such as $2 \mathrm{E} 1 \mathrm{H}$ was confirmed in this case.

It is hoped that this information will be shared with museums in the future, not only to aid earthquake response but also to be of use for museum reconstruction.

\section{ACKNOWLEDGEMENT}

This research was supported by JSPS KAKENHI grant number 26242021.

\section{REFERENCES}

Aldrich, D.P. and Meyer, M., 2015, Social capital and community resilience. American Behavioral Scientist, 59(2), 254-269.

FAIC(The Foundation of the American Institute for Conservation of Historic and Artistic Works), 2006, Field guide to emergency response. 58 .

ICOM Japan, 2015, Stabilization Processing. Multi-Organizational Co-Operative Project for Preserving and Restoring Cultural Assets Damaged by Tsunami on March 11th, 2011.

ICOM Japan, 2018, Stabilization Processing. Multi-Organizational Co-Operative Project for Preserving and Restoring Cultural Assets Damaged by Tsunami on March 11th, 2011. 91.

Izumi, H., 2015, Social memory and social capital in community resilience: reconsidering sociological discourses on post-disaster recoveries and disaster mitigations of local community after the Great East Japan earthquake and Tsunami. MEMOIRS OF FACULTY OF EDUCATION AND HUMAN STUDIES AKITA UNIVERSITY HUMANITIES \& SOCIAL SCIENCES, 70, 9-20. (in Japanese with English abstract)

Kawasaki, E., Matsui, T., Kawamukai, M., Minato, S. and Michimata, J., 2017, Stabilization processes for Tsunami damaged collections of Science Museum of Whale and Sea (Yamada Town, Iwate Prefecture). The 39th Annual Meeting of the Japan Society for the Conservation of Cultural Property, Ishikawa, July 1-2, 30-31. (in Japanese) Kotajima, T., Ro, T., Uchida, Y., Morii, M., Yoshida, N., Kumagai, M., Asakawa, T., Honda, F. and Sano, C., 2018, Naphthalene concentration in a storage of textiles damaged 
by tsunami. The 40th Annual Meeting of the Japan Society for the Conservation of Cultural Property, Kochi, June 16-17, 152-153. (in Japanese)

Matsui, T., Oikawa, T., Kawasaki, E., Atomi, Y., Masuda, R., Nakajima, F., Niinuma, H. and Haga H., 2012, Air quality of museums damaged by the Tsunami - the Case of the Ishinomaki Cultural Center -. The 34th Annual Meeting of the Japan Society for the Conservation of Cultural Property, Tokyo, June 30-July 1, 36-37. (in Japanese)

Matsui, T., Oikawa, T., Kawasaki, E., Haga, A., Masuda, R., Nakajima, F., Sasaki A., Haga, H., Fushimi, T. and Matsumoto, H., 2015, Monitoring and evaluation of air quality in tsunami-affected facilities adapted as temporary storage rooms. The 37th Annual Meeting of the Japan Society for the Conservation of Cultural Property, Kyoto, June 27-28, 34-35. (in Japanese)

Matsui, T., Oikawa, T., Kawasaki, E., Masuda, R., Nakajima, F., Niinuma, H., Sasaki, A. and Haga H., 2013, Air quality of museums and materials damaged by the Tsunami (2) - the Ishinomaki Cultural Center, 17 months later -. The 35th Annual Meeting of the Japan Society for the Conservation of Cultural Property, Miyagi, July 20-21, 50-51. (in Japanese)

Matsui, T., Oikawa, T., Kawasaki, E., Masuda, R., Nakajima, F., Sasaki, A., Haga H., Fushimi, T. and Matsumoto, H., 2014, Air quality of museums and temporary storage facilities damaged by the Tsunami. The 36th Annual Meeting of the Japan Society for the Conservation of Cultural Property, Tokyo, June 7-8, 42-43. (in Japanese)

Matsushita, M., Nishikawa, D., Yasuda, Y. and Amano, M., 2018, Study on odor component of flood damaged ancient documents. The 40th Annual Meeting of the Japan Society for the Conservation of Cultural Property, Kochi, June 15-17, 160-161. (in Japanese)

Mugikura, T. and Yoshino, H., 2013, The issue of disaster prevention and reconstruction in Iwate Prefecture. Japanese Sociological review, 63(4), 402-419.

Oikawa, T. and Haga, A., 2016, Investigation of air quality in
Tsunami-affected museum and its influence on museum artifact materials. Bulletin of Tohoku History Museum, 17, 49-54. (in Japanese)

Oikawa, T. and Haga, A., 2017, Volatile organic compounds from cultural assets damaged by Tsunami (1) - analyses of causal substance of bad odor and their influences on museum artifact materials. Bulletin of Tohoku History Museum, 18, 71-76. (in Japanese)

Oikawa, T., Haga, A. and Moriya, A., 2018, Investigation of volatile substances from various types of water damaged cultural assets after being treated by different drying methods. Bulletin of Tohoku History Museum, 19, 85-88. (in Japanese)

Okada, K., 2017, Construction of a network regarding conservation and exchange of information on cultural property in emergency situations. Science for Conservation, 56, 189-198. (in Japanese with English abstract)

Sano, C., Ro, T., Yoshida, N. and Miura, S., 2010, Conservation theory for museum objects. Mimizuku, 158. (in Japanese)

Sano, C., Uchida, Y. and Akanuma, H., 2017, Analysis of unpleasant odor generated from Tsunami-affected paper materials and hypothesis of its occurrence mechanism. Science for Conservation, 56, 121-133. (in Japanese with English abstract)

Spafford-Ricci, S. and Graham, F., 2000a, The fire at the royal Saskatchewan museum, part 1 : salvage, initial response, and the implications for disaster planning. Journal of the American Institute for Conservation, 39(1), 15-36.

Spafford-Ricci, S. and Graham, F., 2000b, The fire at the Royal Saskatchewan Museum, Part 2 : removal of soot from artifacts and recovery of the building. Journal of the American Institute for Conservation, 39(1), 37-56.

Uchida, Y., Sano, C. and Akanuma, H., 2018, Measurement of water washed paper documents damaged by Tsunami : chloride content and bacteria count. Science for Conservation, 57, 169-179. (in Japanese with English abstract) 